\title{
DESAIN AKUNTANSI ANTI KORUPSI
}

\author{
Taudlikhul Afkar \\ Unversitas PGRI Adi Buana Surabaya \\ afkar@unipasby.ac.id \\ Johan Wahyu Wicaksono \\ STAI Luqman Al-Hakim Surabaya \\ wicaksonoway@gmail.com \\ Ani Faujiah \\ STAI AN-Najah Indonesia Mandiri Sidoarjo \\ anifaujiah99@gmail.com
}

\begin{abstract}
The purpose of this study is to design an ideal accounting to prevent corruption. Qualitative research is used for data analysis with sample research on KJKS Manfat and KJKS Harapan Surabaya. Data triangulation is used to collect data, with data validity tests internally, externally, reliably, and objectively. The analysis technique used is taxonomic analysis by explaining in detail the domain of the results of data collection. The results showed that the ideal accounting design to prevent corruption in a cooperative Islamic financial institution is by running an accounting system in accordance with the SOP, making accounting records based on validated transaction evidence, conducting form forms and functions that can only be used by the agency with the authority in accordance with the functional position, then keep records of transaction evidence in the order in which they were made. The treatment of internal control that is not only in compliance with SOPs such as checking all transaction evidence with a record, but by giving a sense of comfort in doing work and rewarding staff through financial adequacy as a preventive measure to prevent fraud committed so that the system runs in accordance with the rules.
\end{abstract}

Keywords: corruption, accounting system, internal control system, anti-corruption accounting design

\begin{abstract}
ABSTRAK
Tujuan penelitian ini adalah untuk mendesain akuntansi yang ideal untuk mencegah terjadinya korupsi. Kualitatif riset digunakan untuk analisis data dengan sampel penelitian pada KJKS Manfat dan KJKS Harapan Surabaya. Triangulasi data digunakan untuk mengumpulkan data, dengan uji validitas data secara internal, eksternal, reliabel, dan obyektif. Teknik analisis yang digunakan adalah analisis taksonomi dengan cara menjelaskan secara rinci domain dari hasil pengumpulan data. Hasil penelitian menunjukkan bahwa desain akuntansi yang ideal untuk mencegah terjadinya tindakan korupsi pada suatu lembaga keuangan syariah setingkat koperasi adalah dengan cara menjalankan sistem akuntansi sesuai dengan SOP, melakukan pencatatan akuntansi berdasarkan bukti transaksi yang telah divalidasi, melakukan organisasi formulir dengan bentuk dan fungsi yang hanya dapat digunakan oleh lembaga tersebut dengan otoritas sesuai dengan jabatan fungsional, kemudian menyimpan arsip bukti transaksi sesuai dengan urutannya. Perlakuan pada pengendalian internal yang tidak hanya pada ketaatan
\end{abstract}


SOP seperti melakukan pengecekan terhadap semua bukti transaksi dengan catatan, melainkan dengan memberikan rasa nyaman dalam melakukan pekerjaan dan memberikan penghargaan kepada staf melalui kecukupan keuangan sebagai tindakan preventif untuk mencegah terjadinya kecurangan yang dilakukan sehingga sistem berjalan sesuai dengan aturan.

Kata Kunci: Korupsi, Sistem Akuntansi, Sistem Pengendalian Internal, Desain Akuntansi Anti Korupsi

\section{PENDAHULUAN}

Tugas menangani korupsi merupakan tugas yang sangat berat dan membutuhkan dedikasi pengabdian yang tinggi serta penuh kehati-hatian karena tugas tersebut dapat berakibat dan berdampak pada harta dan nyawa baik secara pribadi maupun keluarga. Kebutuhan bertahan hidup serta ancaman kelangsungan hidup menjadikan seseorang dapat cara yang jujur dan tidak jujur. Persaingan dapat menjadi pemicu rasionalisasi ketidakjujuran sehingga menjadi suatu hal yang dianggap logis. Persaingan keras dalam mempertahankan hidup seperti bidang sosial, politik, ekonomi, menyebabkan terjadinya ketidakjujuran sama halnya dalam suatu bisnis (Suradi, 2013).

Korupsi di Indonesia sulit diberantas ini seperti dalam konsep Capture Theory yang menjelaskan bahwa secara yuridis formal segala sesuatu di atas kertas adalah legal dan sah. Realitasnya, teori sering disalahgunakan dalam berbagai hal. Dalam menganalisis kasus korupsi secara sistemik serta konspirasi para pelaku dapat dilakukan dengan pendekatan akuntansi forensik (Wiratmaja, 2010).

Legalitas secara kertas tersebut merupakan dasar pencatatan secara akuntansi, karena bukti transaksi merupakan alat yang sah dan diakui kebenarannya. Permasalahannya adalah bukti transaksi tersebut dibuat secara obyektif atau subyektif, jika bersifat subyektif maka yang terjadi adalah korupsi. Peluang korupsi sangatlah luas baik di lingkungan pemerintahan maupun swasta dalam lingkup besar maupun kecil. Korupsi ini dapat dilakukan sendiri maupun secara lebih dari satu orang. Dalam ilmu akuntansi (Romney, Albrecht, Cherrington, 1980) korupsi merupakan bagian dari kecurangan. Hasil penelitian (Cressey, 1953) kebanyakan orang melakukan korupsi karena kebutuhan, dan istilahnya kecurangan atau ketidakjujuran.

Sistem akuntansi (Mulyadi, 2001) adalah organisasi catatan, formulir, dan laporan agar dapat dijadikan informasi keuangan serta memudahkan manajemen dalam mengelola usaha. Sistem yang sudah ada dalam organisasi yang menjalankan adalah manusia itu 
sendiri, sehingga sebaik apapun sistem itu telah dibuat maka tergantung juga dari orang yang menjalankannya.

Terjadinya penyelewengan maupun kecurangan adalah tindakan yang dilatarbelakangi dengan berbagai motivasi, antara lain karena tekanan, kebutuhan, dan persaingan, selain itu juga karena memang senagaja untuk melanggar aturan demi memenuhi kebutuhan hidup maupun gaya hidup. Tindakan kecurangan itu dapat dikurangi (Wilopo, 2006) dengan mentaati aturan akuntansi, efektifitas dalam pengendalian internal, moralitas manajemen, serta meminimalisir asimetri informasi. Hal ini dikarenakan (Ramamoorti, 2008) perilaku merupakan akar dari permasalahan kecurangan. Sedangkan (Fauwzi, 2011) menyebutkan bahwa pengendalian internal dan moralitas manajemen memberikan dampak menurunnya kecurangan akuntansi.

Hasil penelitian (Mulki, 2011) menunjukkan bahwa penyaluran dana yang terlalu besar dapat mengakibatkan adanya indikasi moral hazard karena cenderung memanfaatkan kelonggaran kebijakan. Sedangkan (Ludigdo, 2006) dalam hasil penelitiannya menunjukkan bahwa pada dasarnya moral hazard yang dilakukan oleh seseorang terjadi karena lemah terhadap godaan dalam profesinya serta rendahnya harga diri. Lemahnya keteguhan hati dan rendahnya kesadaran diri mendorong seseorang untuk melakukan berbagai bentuk moral hazard sehingga ketika muncul suatu peluang yang berpotensi untuk melakukan tindakan penyelewengan dan manipulasi, seseorang akan memanfaatkan ini secara aktif.

Korupsi yang paling sering terekspos secara media adalah terjadi pada instansi pemerintahan karena dalam menjalankan amanat keuangan harus berdasarkan undangundang yang berlaku. Realitanya (Silalahi,1997) korupsi di kalangan juga terjadi dikalangan swasta, seperti kredit macet yang disebabkan adanya kolusi antara pengusaha dengan direktur bank. Korupsi yang terjadi dalam aparatur negara tidak disebabkan karena gaji kecil, sebaliknya yang memiliki gaji besar melakukan korupsi karena ketidakpuasan serta meningkatnya kebutuhan.

Penyelenggaraan pencatatan akuntansi merupakan suatu keharusan dalam kegiatan keuangan karena catatan secara akuntansi ini digunakan untuk membuktikan bahwa telah terjadi transaksi dengan bukti-bukti yang mendukung sehingga dapat dibuktikan dengan cara terbalik. 
Sistem merupakan kesatuan yang tidak dapat dipisahkan satu dengan yang lainnya. Artinya berjalannya suatu sistem didasari oleh beberapa komponen yang ada pada sistem tersebut. Koperasi jasa keuangan syariah merupakan organisasi badan hukum yang memiliki sistem didalamnya yang diatur dalam Undang-undang perkoperasian dan Standart Operating Procedure (SOP) secara internal. Sistem tersebut dibuat dan dijalankan oleh manusia, sementara sifat manusia berbeda anatara satu dengan lainnya, oleh karena itu apabila terjadi salah satu komponen tidak berjalan dengan semestinya maka sistem tersebut mengalami permasalahan.

Pengendalian internal merupakan suatu bentuk perencanaan untuk mengendalikan jalannya suatu usaha sehingga diperlukan metode dan kebijakan dalam mengawasi kegiatan usaha. Pengendalian internal dilakukan untuk mengantisipasi adanya tindakan yang tidak dinginkan dengan cara tindakan preventif, tindakan detektif dan tindakan korektif atau represif. Perilaku manusia dalam menjalankan sistem akuntansi suatu usaha terutama koperasi memiliki perbedaan yang siginfikan dengan latar belakang yang berbeda sehingga memungkinkan adanya tindakan yang salah.

Hakim (2014) akuntansi dapat digunakan untuk membuktikan adanya kerugian atas terjadinya kasus yang berindikasi tindakan korupsi. Keterkaitan dengan sistem akuntansi dalam menghindari tindakan korupsi adalah pengunaan sistem yang dijalankan dengan berbagai macam pengendalian internal dalam Koperasi jasa keuangan Syariah tersebut. Sementara lembaga keuangan syariah jarang sekali terdengar adanya tindakan korupsi apalagi dalam lembaga keuangan setingkat Koperasi. Legalitas secara kertas dan melemahnya keteguhan hati inilah yang mendasari peneliti untuk mengembangkan desain akuntansi untuk mencegah atau mengantisipasi terjadinya tindakan korupsi pada lembaga keuangan syariah yaitu Koperasi Jasa keuangan Syariah Pusat di Jawa Timur.

Koperasi Jasa keuangan syariah (KJKS) adalah lembaga keuangan yang melakukan pencatatan akuntansi secara syariah. Secara kelembagaan, organisasi, dan personalia seharusnya sudah memiliki integritas dalam hal keuangan secara syariah dan menjalankan tugas masing-masing berdasarkan prinsip Islam. Pengawasan secara internal dalam hal pencatatan akuntansi dan pelaksanaan prosedur sesuai dengan ketentuan internal lembaga merupakan hal yang harus dijalankan.

Permasalahan yang dihadapi adalah dengan sistem akuntansi yang ada maka bagaimanakah desain akuntansi yang dapat mencegah terjadinya tindakan korupsi 
sehingga dalam penelitian ini memiliki desain akuntansi yang ideal untuk mencegah terjadinya tindakan korupsi. Kontribusi penelitian ini diharapkan 1) memberikan alternatif bentuk akuntansi yang dapat mencegah terjadinya tindakan korupsi, 2) memberikan pemahaman kepada masyarakat pentingnya obyektifitas dalam kegiatan keuangan, 3) menanamkan jiwa yang bersih terhadap segala tindakan korupsi, 4) membentuk personal yang taat pada aturan demi tercapainya situasi dan kondisi yang baik untuk kemajuan bangsa, 5) erciptanya Good Corporate Governance.

Mendesain suatu bentuk kebijakan memerlukan kajian yang luas secara makro dan membutuhkan waktu yang cukup lama agar hasilnya lebih baik yang pada akhirnya dapat di generalisasi untuk umum. Oleh karena itu penelitian tentang Mendesain Akuntansi Anti Korupsi ini terbatas pada menggali informasi serta mendapatkan data yang sesuai dengan karakteristik penelitian ini yaitu pada sistem akuntansi dan pengendalian internal pada Pusat Koperasi Jasa Keuangan Syariah di jawa Timur. Pusat Koperasi Jasa Keuangan Syariah Jawa Timur ini bergerak dibidang Simpan Pinjam sehingga penelitian ini terbatas pada sistem akuntansi pengendalian internAl simpan pinjam yang dilaksanakan.

\section{LANDASAN TEORI}

\section{Teori Korupsi dan Anti Korupsi}

\section{Teori GONE}

Perilaku korupsi merupakan tindakan tidak baik yang dilatarbelakangi berbagai macam alasan yang dikenal dengan teori GONE (Bologne and Linquist, 1995). GONE Theory berhubungan dengan penyebab terjadinya korupsi yaitu Greeds (keserakahan), Opportunities (kesempatan), Needs (kebutuhan) dan Exposure (pengungkapan).

\section{Teori Solidaritas Sosial}

Teori Solidaritas Sosial dikembangkan oleh Emile Durkheim (1964), menjelaskan mengenai watak manusia yang bersifat pasif serta ada kendali oleh lingkungan. Individu membentuk kepribadiannya secara netral, moral melalui lingkungan masyarakat. Lingkungan masyarakatlah yang mengendalikan watak manusia melalui maka norma dan nilai yang ada (Angha, 2002). Artinya masyarakat berpengaruh besar dalam pembentukan prilaku individu. Dengan demikian bila ada sistem korupsi menjadi budaya maka individu yang terbentuk juga korup.

\section{Teori means-ends scheme}


Robert Merton mengenalkan teori means-ends scheme. Korupsi merupakan perilaku manusia yang disebabkan karena adanya tekanan social yang mengakibatkan terjadinya pelanggaran norma-norma. Sehingga pada akhirnya seseorang berusaha mendapatkannya melalui cara-cara yang disepakati bersama (Handoyo, 2009).

\section{Penyebab Korupsi}

Korupsi menjadi pembahasan yang tidak ada akhirnya. Faktor internal penyebab tindakan korupsi adalah sifat tamak dan rakus yang tidak ada puasnya dengan segala kecukupan yang dimiliki. Moral yang tidak kuat akan mudah tergoda melakukan korupsi. Perilaku curang juga dapat dipengaruhi keluarga. Pandangan behavioris menjelaskan bahwa keluarga merupakan faktor dominan untuk korupsi sehingga mampu menggoyahkan sifat pribadi seseorang yang pada dasarnya sudah baik.

Faktor eksternal yang mendorong seseorang untuk melakukan korupsi biasanya terjadi secara sistemik. Saling menutupi tindakan curang dalam organisasi berpotensi meningkatnya tindakan korupsi. Masyarakat tidak sadar dimana sebenarnya adalah masyarakat sendiri (Kemdikbud, 2011). Pendapatan rendah menyebabkan kesulitan ekonomi sehingga membuka peluang seseorang melakukan korupsi. Perlu adanya kontrol sosial untuk mempengaruhi orang-orang agar bertindak sesuai norma masyarakat (Rahardjo, 1983).

Disiplin, tanggungjawab, kerja keras merupakan tindakan yang harus dibangun untuk membentuk karakter anti korupsi (Afkar, Miradji, Hariawan, 2018a). Ketika pemimpin tidak mampu memberi teladan baik pada bawahannya, maka sangat memungkinkan bawahan akan berperilaku sama dengan atasannya.

\section{Nilai dan Prinsip Anti Korupsi}

Nilai-nilai dalam anti korupsi merupakan pengembangan dari pribadi masingmasing orang yang dapat diwujudkan melalui (Sugono, 2008 ; Supardi, 2004; Sjaifudin, 2002) kepedulian, kerja keras, kejujuran, kesederhanaan, kemandirian, keberanian, kedisiplinan, serta keadilan. Sedangkan Prinsip anti korupsi dapat diwujudkan dengan berpegang teguh pada pendirian yang benar serta akuntabilitas.

Akuntabilitas merupakan kesesuaian antara pelaksanaan kerja dengan aturan yang ada. Pertanggunngjawaban kinerja sesuai aturan baik dalam bentuk konstitusi (de jure) maupun konvensi (de facto). Akuntabilitas dapat dipahami sebagai alat untuk pengawasan administrasi agar dapat memberikan jawaban (answerability) pada otoritas eksternal 
(Dubnick, 2005). Selain itu akuntabilitas publik secara fundamental mengarah pada kemampuan menjawab seseorang berhunbungan dengan kinerjanya (Pierre,2007).

Transparansi juga prinsip penting karena pemberantasan korupsi dapat dimulai dari transparansi yang mengharuskan semua proses kebijakan secara terbuka, sehingga penyimpangan dapat diketahui oleh publik (Prasojo, 2007). Selain itu perlu juga adanya penerapan kejujuran, kepedulian, dan kemandirian agar mampu mengantisipasi mencegah korupsi (Afkar, Miradji, Hariawan, 2018a).

\section{Tindakan Curang (Fraud)}

Tindakan Curang menurut (Albrecht and Albrecht, 2003) yaitu disebabkan adanya kesempatan (perceived opportunity), adanya tekanan (perceived pressure), dan berbagai cara untuk merasionalkan agar kecurangan dapat diterima. Tekanan menciptakan adanya kebutuhan akan uang sehingga dapat mendorong untuk korupsi. Pelaku kecurangan biasanya memiliki peluang dan pengetahuan berlaku curang karena kaktor utama peluang terletak di pengendalian intern. Lemahnya pengendalian intern merupakan peluang bagi pelaku. Ketika motivasi bertemu dengan peluang, maka memungkinkan kecurangan meningkat (Cressey, 1953).

Kesempatan sebenarnya merupakan otoritas atau kewenangan untuk mengendalikan suatu aset. Dapat dikatakan juga memiliki akses yang mudah. Kesempatan dapat menimbulkan seseorang melakukan tindakan curang kemudian menyembunyikannya (shleifer dan Robert, 1993). Sedangkan rasionalisasi merupakan pembenaran tentang apa saja yang kita lakukan dengan tujuan subyektif, meskipun tanpa dasar yang kuat.

\section{Desain Akuntansi}

Akuntansi memiliki peran yang vital dalam kegiatan usaha yang dapat digunakan sebagai alat perencanaan serta alat evaluasi hasil kegiatan. Akuntansi berperan sebagai alat perencanaan ketika manajemen ingin mengetahui operasional usahanya dalam tiap periode termasuk asset, utang, dan ekuitas dimana semuanya dapat diketahui dari catatan akuntansi. Selain itu juga dapat digunakan untuk penganggaran keuangan pada periode berikutnya. Sedangkan akuntansi berperan sebagai alat evaluasi hasil kegiatan ketika manajemen ingin membandingkan realisasi dengan perencanaan. Tentunya setiap peristiwa mengakibatkan perubahan-perubahan pada posisi keuangan melalui transaksi. 
Transaksi dalam perusahaan dapat dibedakan menjadi dua yaitu transaksi internal dan eksternal (Afkar, 2015).

Komponen yang saling ketergantungan sehingga tidak dapat dipisahkan untuk mencapai tujuan tertentu disebut sebagai sistem (Gitosudarmo dan Najmudin, 2003). Dalam sistem akuntansi terdapat beberapa komponen yang tidak dapat dipisahkan yang menyesuaikan ukuran dan jenis organisasi. Sistem akuntansi (Mulyadi, 2001) sebenarnya dapat dikatakan sebagai organisasi laporan yang terbentuk dari formulir dan catatan untuk menyediakan informasi keuangan.

Sistem akuntansi dirancang untuk memenuhi kebutuhan informasi bagi perusahaan selama informasi tersebut tidak mahal. Pertimbangan penting dalam perancangan sistem akuntansi adalah keseimbangan antara biaya dan manfaat yang dikeluarkan dalam rangka mendapatkan informasi tersebut (Afkar, 2015).

Sistem akuntansi dapat dikatakan sebagai alat yang digunakan dalam mengolah data melalui prosedur catatan untuk mendapatkan umpan balik berupa laporan agar dapat mengawasi usahanya maupun dari pihak eksternal yang berhubungan dengan usahanya (Krismiaji, 2005). Sistem akuntansi berfungsi untuk menghasilkan informasi akuntansi yang tepat relevan, waktu, dan dapat dipercaya. Tujuannya adalah memberikan informasi pengelolaan usaha, meningkatkan informasi yang sudah ada seperti ketepatan penyajian laporan, mutu, serta struktur informasinya, selain itu untuk pengendalian akuntansi internal seperti reliabilitas informasi akuntansi menjadi lengkap sebagai pertanggungjawaban dan perlindungan aset perusahaan, serta mengurangi biaya klerikal (Mulyadi,2001), sehingga dapat dijadikan sebagai alat komunikasi untuk keperluan internal dan eksternal (Krismiaji, 2005).

Implementasinya dilakukan oleh seluruh komponen yang ada dalam sistem tersebut yang dilakukan secara hati-hati dan selalu dilakukan untuk meminimalkan terjadinya kesalahan yang tidak disengaja maupun disengaja (Mulyadi, 2001).

\section{Sistem Pengendalian Internal}

Perencanaan dengan menggunakan alat serta metode yang digunakan dalam rangka menjaga keamanan asset perusahaan, pemeriksaan akuntansi, efisiensi, serta membantu kepatuhan kebijakan menejemen perusahaan dapat disebut sebagai Sistem Pengendalian Internal. Pengendalian internal mencakup kebijakan, prosedur, serta satukesatuan sistem informasi (Rama dan Jones, 2008). Tujuannya untuk mengurangi 
terjadinya kesalahan dalam mencapai tujuan, serta berorientasi pada kepatuhan karyawan dalam mengikuti kebijakan perusahaan (Krismiadji, 2005).

Pengendalian internal merupakan tanggungjawab manajer yang memiliki sasaran pada efektifitas dan efisiensi operasional, laporan keuangan, taat hukum dan peraturan, serta kemananan asset perusahaan (Rama dan Jones, 2008). Konsep pengendalian internal mengacu pada pengendalian preventif atau pencegahan masalah sebelum terjadi, pengendalian detektif atau menemukan masalah setelah terjadi, dan selanjutnya pengendalian korektif untuk pemecahan masalah (Krismiadji, 2005). Efektifitas pengendalian internal membantu organisasi mencapai tujuan kinerja, pelaporan keuangan dan non keuangan, dan kepatuhan terhadap peraturan (Tampubolon, 2005).

The foreign corrupt practice act merupakan peraturan yang mengharuskan perusahaan memiliki catatan yang akurat dan jujur dengan sebuah sistem pengendalian akuntansi internal yang memadai untuk memberikan bahwa cakupan transaksi sudah diotorisasi dan dicatat secara tepat, asset dijaga dan dilindungi dari akses yang tidak sah, nilai asset tercatat secara periodik (US Government, 1976). Pencegahan aksi suap oleh pihak luar terhadap internal untuk memperoleh kesepakatan bisnis dan menciptakan pengendalian internal yang kuat merupakan tujuan utama peraturan The foreign corrupt practice act (US Government, 1976).

Kecurangan dalam akuntansi dapat disebabkan berbagai macam latar belakang, pencegaha yang dapat dilakukan (Afkar, 2016) melakukan pengendalian prevenitif, detektif, dan represif. Pengendalian preventif tifsk sepenuhnya mampu mengantisipasi kecurangan, namun pengendalian detektif dan represif dapat dilakukan karena kebiasannya adalah kecurangan terjadi lebih dulu kemudian dicari kesalahannya serta tindakaan hukuman (Afkar, 2016)

\section{METODOLOGI PENELITIAN}

\section{Desain dan Metode Penelitian}

Penelitian explanatory digunakan karena penelitian ini bersifat fundamental dengan tujuan mendapatkan informasi, keterangan, serta hal-hal yang belum diketahui. Sehingga untuk mendapatkan data tersebut memerlukan ekplorasi dengan cara menyiapkan beberapa desain pertanyaan untuk memperoleh data primer. Selanjutnya akan diperkuat 
dengan data-data sekunder berupa dokumentasi melalui observasi kemudian di interpretasikan.

\section{Subyek Penelitian}

Populasi pada Pusat Koperasi Jasa Keuangan Syariah di Jawa Timur Jumlahnya cukup banyak namun dari keseluruhan jumlah populasi tersebut tidak semuanya ikut serta dalam anggota Pusat Koperasi Jasa Keuangan Pusat Jawa Timur. Populasi anggota Koperasi Jasa Keuangan Syariah Jawa Timur terdapat pada tabel berikut ini.

Tabel 1

Profil Pusat KJKS Jawa Timur

\begin{tabular}{|c|l|c|l|}
\hline No & \multicolumn{1}{|c|}{ Nama } & No & \multicolumn{1}{c|}{ Nama } \\
\hline 1 & KJKS Harapan Surabaya, Surabaya & 13 & KJKS Wanita Khadijah, Surabaya \\
\hline 2 & KJKS Manfaat, Surabaya & 14 & KSSU Harum Dhaha, Kediri \\
\hline 3 & KJKS Sari Anas, Surabaya & 15 & BMT Muda, Surabaya \\
\hline 4 & Kopsyah Amanah, Nganjuk & 16 & BMT Mandiri Berkah Sejahtera, Madiun \\
\hline 5 & KJKS Arofah, Tulungagung & 17 & KJK SyariahMadani, Trenggalek \\
\hline 6 & KJKS Bina Potensi Umat, Pasuruan & 18 & $\begin{array}{l}\text { KJKS MuamalahBerkah Sejahtera, } \\
\text { Surabaya }\end{array}$ \\
\hline 7 & BMT EL Puspo Jagad, Blitar & 19 & KJKS Mandiri Sejahtera, Gresik \\
\hline 8 & KJKS Bina Umat, Jember & 20 & KJKS PilarMandiri, Surabaya \\
\hline 9 & BMT Permata, Mojokerto & 21 & BMT BinaTanjung, Jember \\
\hline 10 & KJKS Artha Kelola Sejahtera, Bojonegoro & 22 & KJKS Sri Sejahtera, Surabaya \\
\hline 11 & KJKS Bersama, Surabaya & 23 & BMT Harapan Ummat, Sidoarjo \\
\hline 12 & Kopwan Syariah Sejahtera, Lamongan & 24 & UJKS Koptanu, Malang \\
\hline
\end{tabular}

Sumber : Pusat KJKS Jawa Timur

Pengambilan sampel sebagai subyek penelitian yang digunakan dalam penelitian ini adalah teknik Purposive Sampling. Menurut Sugiyono (2009) merupakan pengambilan sampel berdasarkan kriteria dan pertimbangan tertentu. Berdasarkan tenik pengambilan sampel yang menggunakan Purposive Sampling maka dari jumlah populasi dapat diambil sampel sebanyak dua yaitu pada :

1. Koperasi Jasa Keuangan Syariah (KJKS) Harapan Surabaya

2. Koperasi Jasa Keuangan Syariah (KJKS) Manfaat

Sampel sebagai subyek penelitian tersebut diambil berdasarkan pertimbangan dan kriteria tertentu yang menunjukkan bahwa sampel tersebut dapat mewakili dari jumlah populasi yang ada. Pertimbangan dan kriteria yang digunakan adalah :

1. Koperasi Jasa keuangan Syariah Harapan Surabaya dan Koperasi Jasa Keuangan Manfaat merupakan inisiator untuk mendirikan dan menjadikan satu keanggotaan yang tersebar di Jawa Timur menjadi Pusat Koperasi Jasa Keuangan Syariah 
2. Koperasi Jasa keuangan Syariah Harapan Surabaya dan Koperasi Jasa Keuangan Manfaat tersebut merupakan pusat dan tempat untuk mewadahi segala bentuk perkembangan tentang Koperasi Syariah

3. Koperasi Jasa keuangan Syariah Harapan Surabaya dan Koperasi Jasa Keuangan Manfaat merupakan koperasi yang paling lama berdirinya sehingga dapat mewakili koperasi syariah lainnya.

\section{Obyek Penelitian}

Obyek penelitian yang digunakan adalah pada Sistem Akuntansi dan Pengendalian Internal pada Pusat Koperasi Jasa Keuangan Syariah Jawa Timur. Penggunaan Sistem Akuntansi dan Pengendalian Internal sebagai obyek penelitian karena Sistem Akuntansi merupakan suatu kesatuan atas berbagai macam komponen yang tidak dapat dipisahkan yang membentuk suatu catatan yang pada akhirnya digunakakan sebagai pedoman dan prosedur dalam pencatatan akuntansi. Sedangkan penggunaan Pengendalian Internal adalah untuk mengetahui bagaimana tindakan preventif untuk mencegah atau mengantisipasi agar sesuatu yang tidak diinginkan tidak terjadi, detektif untuk mencari segala bentuk yang sekiranya salah sehingga dapat diketahui letak permasalahan dan diperbaiki, korektif atau represif adalah suatu bentuk tindakan untuk mengevaluasi kesalahan sehingga dapat diperbaiki ke arah yang lebih baik dalam rangka mencegah tindakan korupsi dalam suatu lembaga terutama keuangan syariah yang menjadi subyek dan sampel dalam penelitian ini.

\section{Teknik Pengumpulan Data}

Teknik triangulasi digunakan dalam pengumpulan data. Dokumentasi digunakan untuk mendapatkan metode pencatatan akuntansi yang digunakan. Wawancara terstruktur dan tidak terstruktur yang digunakan untuk mendapatkan ide, gagasan, dan mendiskusikan desain yang ideal untuk mendapatkan desain akuntansi anti korupsi dalam rangka mencegah tindakan korupsi. Observasi dilakukan untuk mendapatkan data melalui pengamatan.

\section{Teknik Analisa Data}

Teknik analisis data digunakan untuk menganalisis data yang sudah dikumpulkan sehingga dapat menjawab rumusan masalah yang sudah dirumuskan dalam desain penelitian. Analisis dalam penelitian ini menggunakan analisis taksonomi (Spradley dalam Sugiyono, 2009), karenakan domain atau fokus dalam penelitian ini sudah 
ditentukan sehingga selanjutnya setelah mendapatkan data yang telah diuji validitasnya maka akan jelaskan secara lebih rinci dan lebih mendalam shingga dapat menjawab rumusan masalah yang sudah dirumuskan sebelumnya. Analisis ini juga sama yang digunakan oleh (Shafique,dkk 2012).

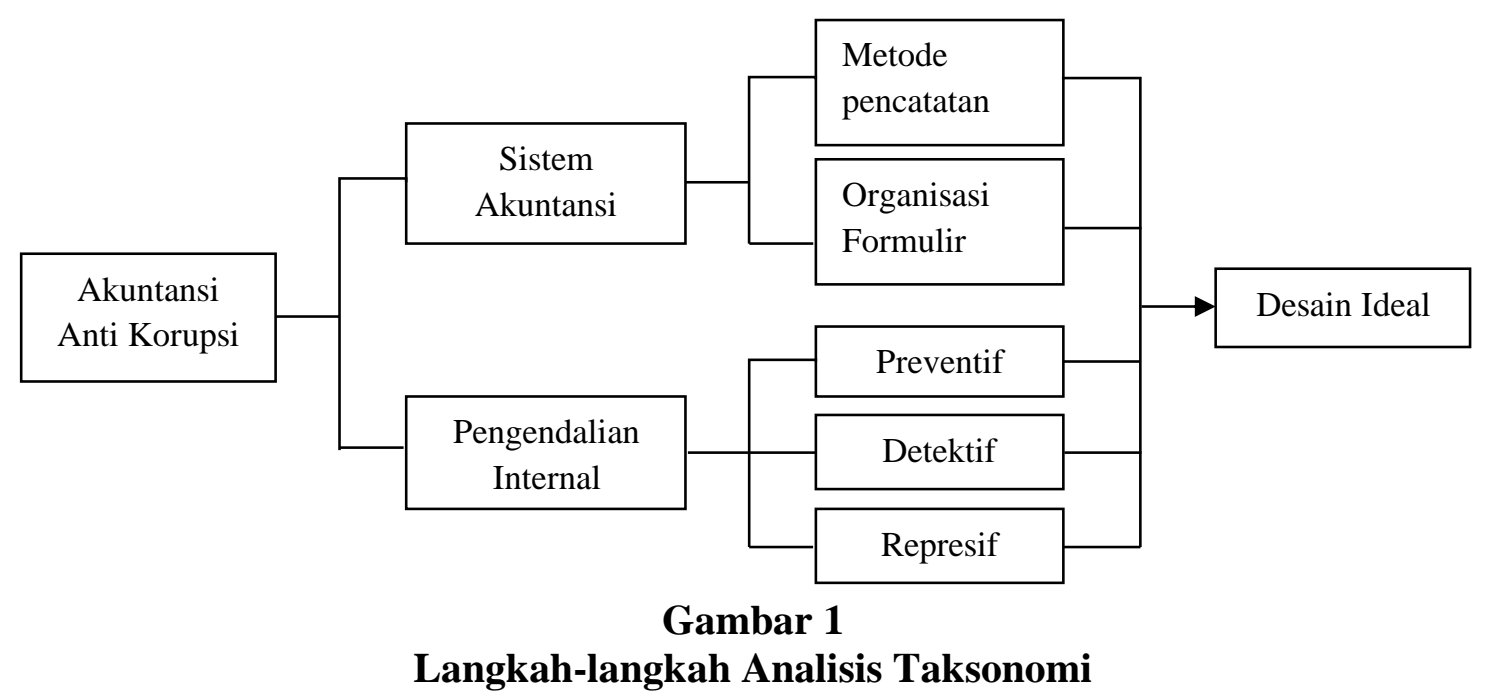

Pada gambar 1 menjelaskan tentang langkah-langkah analisis taksonomi yang dimulai dari teori tentang korupsi yang dihubungkan dengan akuntansi. Kemudian membagi teori tersebut ke dalam indikator Sistem akuntansi yang akan dijelaskan mengenai metode pendatatan dan organisasi formulir dalahal ini adlah bukti transaksi. Selanjutnya menjelaskan tentang pengendalian internal yang dlakukan melalui tindakan preventif, detektif, dan represif sehingga diharapkan hasilnya adalah suatu desain yang ideal mengenai akuntansi anti korupsi.

\section{PEMBAHASAN}

\section{Desain Akuntansi Anti Korupsi}

Desain merupakan suatu bentuk, pola, gambaran, rencana atas sesuatu yang akan dikerjakan. Mendesain berarti melakukan sesuatu untuk mendapatkan bentuk, pola, gambaran maupun perencanaan atas sesuatu yang sedang dikerjakan. Pembahasan dalam penelitian ini adalah bagaimana mendesain akuntansi anti korupsi, sehingga mendesain akuntansi anti korupsi ini merupakan melakukan tindakan untuk mendapatkan bentuk, pola, gambaran yang ideal dengan bebagai alat yaitu teori, metodologi, dan data yang 
berhubungan dengan akuntansi dan korupsi sehingga dapat dibuat untuk mendesain akuntansi anti korupsi.

Penyusunan desain akuntansi anti korupsi ini melewati beberapa tahapan yang dimulai dari studi literatur untuk mendapatkan gambaran tentang berbagai macam tindakan korupsi dengan berbagai motivasi yang mendasarinya. Selanjutnya studi tentang akuntansi yang diperoleh dari sistem akuntansi dan sistem pengendalian internal. Beberapa studi literatur tersebut diaplikasikan kedalam latar belakang dan kerangka teori yang akan menjadi dasar dalam menjawab permasalahan yang diajukan dan akan dibahas dalam pembahasan ini.

Penerapan peranan akuntansi dalam penelitian ini dapat dilihat pada KJKS Manfaat dan KJKS Harapan Surabaya bahwa kedua koperasi syariah tersebut menerapkan pernana akuntansi dalam perencanaan dapat dilihat melalui perencanaan penerimaan atas piutang dari anggota keoperasi yang memiliki pinjaman. Perencanaan ini dapat dilihat dari bukti catatan yang dilakukan oleh masing-masing KJKS pada catatan pembiayaan yang diberikan melalui akad pembiayaan dan angsuran yang dicatat ke dalam buku pembantu piutang atas nama anggota koperasi yang memiliki pinjaman dengan umur piutang atau jatuh tempo tagihan yang sudah diketahui. Selain itu juga terdapat pada kewajiban yang harus dibayar oleh kedua KJKS ini melalui jumlah simpanan yang akan diambil oleh anggota dimana pada saat akan mengambil dalam jumlah yang besar maka anggota diharapkan memberitahukan terelebih dahulu agar secara administrasi dan kecukupan likuiditas kas pada saat itu mencukupi.

Penerapan peranan akuntansi sebagai alat evaluasi pada kedua KJKS dilakukan dengan cara yang sedikit berbeda. Evaluasi yang dilakukan pada KJKS Manfaat terhadap catatan semua transaksi terutama kas dilakukan setiap hari, mulai dari bukti transaksi yang sudah divalidasi sampai pada jumlah uang yang ada pada kas harian dengan jumlah yang sama kemudian dibuat rekapitulasinya dengan mengelompokkan sesuai nilai nominal masing-masing sehingga jelas dan terakumulai. Evaluasi ini dilakukan oleh Manajer sebagai penanggungjawab pengelolaan koperasi. Sedangkan pada KJKS Harapan Surabaya melakukan evaluasi terhadap semua catatan yang berhubungan dengan keuangan terutama kas harian yang dilakukan setiap hari ketiga dan hari terakhir sebelum libur pada minggu yang sama namun tidak melakukan rekapitulasi terhadap uang kas sesuai dengan nominal masing-masing hanya dengan cara menjumlahkan uang yang ada 
kemudian menyesuaikan dengan bukti transaksi yang sudah divalidasi. Evaluasi ini juga dilakukan oleh Manajer selaku penganggungjawab operasional koperasi.

Pengendalian internal pada KJKS Manfaat dan KJKS harapan surabaya pada penerapan peranan akuntansi pada dasarnya sama yaitu mngacu kepada ketaatan dalam pelaksanaan SOP yang telah dibuat dan diberlakukan pada masing-masing KJKS. Perbedaan yang terlihat adalah pada pemeriksaan catatan kas oleh KJKS Manfaat dilakukan setiap hari dan pada KJKS Harapan Surabaya dilakukan minimal pada hari ketiga. Menurut teori GONE pada huruf $\mathrm{O}$ yang menunjukkan ada peluang dalam melakukan tindakan yang tidak semestinya terlihat pada kegiatan pengecekan oleh Manajer pada hari ketiga. Peluang yang dimaksud adalah dalam jangka waktu tiga hari bisa saja seseorang melakukan tindakan yang tidak semestinya.

Aplikasi Teori GONE pada huruf O atau Opportunity (peluang) terlihat pada KJKS Harapan surabaya bahwa dalam pemeriksaan dengan rentang waktu 3 (tiga) hari bisa saja staf yang keuangan yang diberikan otoritas untuk melakukan pencatatan setiap transaksi keuangan ini melakukan tindakan dengan mengurangi jumlah uang yang dipegang dan merubah atau mengganti bukti transaksi yang ada dengan menyesuaikan nominal uang kas yang sudah dikurangi. Akan tetapi pada KJKS Harapan Surabaya tidak terjadi tindakan yang demikian, meskipun pengecekan oleh Manajer dilakukan tiga hari tidak terjadi tindakan tersebut. Hal ini dilakukan oleh manajer dengan antisipasi pada pemberian gaji yang lebih tinggi dari standar gaji pemerintah mengingat kebijakan ini dilakukan karena jumlah staf yang sedikit dengan pekerjaan yang dapat dirangkap meskipun secara deskripsi pekerjaan tidak merupakan tanggungjawabnya.

Tekanan keuangan, kebiasaan buruk, tidaka adanya penghargaan atas kinerjanya, sifata tidak puas, tidak mendapatkan perhatian, takut kehilangan jabatan, promosi tidak ada merupakan faktor pendorong terjadinya kecurangan (Albrecht, 2003). Penjelasan Albercht (2003) tersebut telah diantisipasi oleh Manajer KJKS harapan Surabaya dan KJKS manfaat dengan suatu pengendalian internal yang bersifat preventif dengan cara memberikan rasa nyaman terhadap pekerjaan meskipun banyak yang dikerjakan dan penghargaan terhadap kinerjanya yang salah satunya dinilai dengan gaji yang cukup. Meskipun pada KJKS Manfaat sebenarnya juga memberikan gaji yang sesuai dengan aturan pemerintah tentang pengupahan namun tidak sebesar pada KJKS Harapan Surabaya. 
KJKS Manfaat dan KJKS Harapan Surabaya dalam SOP yang digunakan terdapat sistem akuntansi yang digunakan dengan pedoman standar akuntansi keuangan secara syariah seperti dalam pernyataan Afkar (2015) bahwa akuntansi merupakan seni pencatatan, penggolongan, peringkasan yang dinilai dengan satuan uang dengan proses indetifikasi, pengukuran, sampai pada pelaporan. Pencatatan akuntansi yang dilakukan oleh KJKS Manfaat dan KJKS harapan Surabaya sudah dilakukan sesuai dengan pengertian akuntansi. Pencatatan tersebut dapat dilihat dari masing-masing KJKS dalam menerapakan pencatatan atas bukti transaksi yang ada. Identifikasi yang dilakukan adalah pada bukti transaksi seperti akad simpanan, akan pembiayaan, slip setoran, slip penarikan, slip angsuran dengan cara membedakan dan memisahkan setiap bukti transaksi tersebut sehingga dapat diukur nilai nominal yang ada pada setiap bukti transaksi sehingga dapat dilaporkan dengan bukti yang otentik secara akuntabel.

Pada proses pencatatan, penggolongan dan peringkasan juga mengacu pada seni pencatatan dalam akuntansi dengan melakukan pencatatan berdasarkan bukti transaksi yang telah divaidasi sebelumnya oleh bagian masing-masing yang memiliki otoritas dalam pengawasan Manajer. Pencatatan yang dilakukan adalah untuk simpanan dicatat sebagai kewajiban yang harus dibayar kembali kepada anggota karena simpanan merupakan titipan dana dari anggota dengan memberikan jasa atas simpanan tersebut pada akhir periode dengan perhitungan yang sudah ditentukan sesuai dengan akad simpanan. Begitu juga dengan pencatatan pada akad pembiayaan dicatat sesuai dengan pencatatan pembiayaan dengan mengakui pembiayaan itu sebagai pencapatan usaha atas dana yang diberikan kepada anggota. Pendapatan tersebut merupakan piutang dan penerimaannya melalui angsuran. Perbedaan pencatatan angsuran dari KJKS Manfaat dan KJKS harapan Surabaya terletak pada bukti transaksinya. KJKS Manfaat menggunakan bukti transaksi slip angsuran dan catatan tersebut direkap pada kartu angsuran, sedangkan pada KJKS Harapan Surabaya tidak menggunakan kartu angsuran pencatatannya langsung dicatat pada buku kas harian yang kemudian di entri pada komputer sebagai catatan angsuran dari anggota.

Proses pencatatan secara akuntansi sama hanya saja perbedaannya terletak pada dokumentasi dari bukti transaksi. KJKS manfaat melengkapi bukti transaksi dengan kartu angsuran yang sudah tercetak dalam bentuk form sedangkan KJKS Harapan Surabaya mencatat angsuran ke dalam komputer dengan form yang ada. Secara efisiensi 
lebih efisien yang dilakukan oleh KJKS harapan Surabaya karena tidak memerlukan proses yang lama dengan bukti transaksi yang banyak. Kelemahannya adalah jika data yang tercatat pada komputer tidak di backup atau memiliki catatan cadangan maka akan hilang pada saat system komputer mengalami kerusakan. Pada KJKS manfaat memang memiliki bukti yang cukup lengkap berkaitan dengan pencatatan transaksi, prosesnya menjadi lebih lama karena sebelum memasukkan data entri ke komputer masih harus melengkapi catatan pada kartu angsuran. Akan tetapi secara mekanisme pencatatan akuntansi dalan pelaporannya adalah sama.

Pengendalian internal yang dilakukan Manajer pada proses pencatatan ini adalah memastikan semua bukti transaksi adalah sesuai mulai dari jenis bukti transaksi sampai pada pencatatan yang dilakukan, sehingga penggolongan dan peringkasan terhadap catatan akuntansi dapat mudah diketahui. Seperti yang terlihat pada sistem akuntansi simpanan dan sistem akuntansi pembiayaan yang digunakan oleh kedua KJKS dalam membuat laporan. Semua bukti transaksi yang berhubungan dengan simpan pinjam yang telah dicatat kemudian disimpan ke dalam odner sesuai dengan jenis bukti transaksi dan terjadinya tanggal transaksi. Pengendalian internal yang dillakukan oleh manajer tersebut sesuai dengan fungsi pada sistem akuntansi (Krismiaji, 2005)

Sistem yang diterapkan dalam akuntansi dan pengendalian internal oleh kedu KJKS mengacu pada pemahaman sistem oleh (Gitosudarmo dan Najmudin, 2003; Afkar, 2015) bahwa sistem merupakan kumpulan komponen yang saling berinteraksi untuk mencapai tujuan tertentu.

Sistem akuntansi dan pengendalian internal yang dilakukan dengan menggunakan SOP yang diberlakukan dan menerapkan kepada staf dengan sistem otorisasi sesuai dengan jabatan masing-masing. Alur dalam penyampaian informasi terhadap semua bukti transaksi juga sudah jelas sesuai dengan struktur organisasi yang ada sehingga secara sistem sudah dijalankan dengan benar akan tetapi jika mengacu pada SOP yang diberlakukan ada sedikit celah kekurangan bahwa setiap pemberian otoritas akan memberikan kelancaran dalam menjalankan tugas tetapi yang terjadi pada sistem otoritas ini adalah rangkap artinya bahwa pada jabatan fungsional dalam organisasi masih terdapat pekerjaan yang dirangkap atau tidak sesuai dengan deskripsi pekerjaan. Hal ini dilakukan sesuai dengan yang disampaikan oleh Afkar (2015) bahwa merancang sistem perlu diperhatikan manfaat dan biaya yang dikeluarkan oleh koperasi. Dalam 
kegiatan ini sistem otoritas dengan berbagai macam pekerjaan memberikan manfaat yang sesuai dengan output yang diinginkan dengan hanya memanfaatkan staf dengan jumlah sedikit sehingga sistem tetap berjalan dengan baik namun dengan adanya kebijakan dalam penghargaan atas pekerjaan yang dilakukan oleh staf dengan memberikan gaji yang lebih besar.

Sistem yang dijalankan juga bermuara pada pertanggungjawaban laporan kepada anggota koperasi sehingga pengendalian internal oleh manajer dan pengawasan oleh pengurus dilakukan dengan SOP yang ada sebagaimana menurut Howard F. Settler (dalam Krismiaji, 2005) Sistem akuntansi merupakan prosedur, catatan, dan formulr serta alat-alat yang digunakan mengolah data hasil usaha untuk menghasilkan laporan sehingga manajemen melakukan pengawasan, dan bagi pihak-pihak eksternal untuk menilai hasil operasi usaha.

Desain akuntansi anti korupsi berdasarkan hasil penelitian dengan obyek penelitian Koperasi Jasa Keuangan Syariah yang sudah dianalisis dengan berbagai macam teori menunjukkan bahwa desain akuntansi korupsi yang didapatkan adalah menentukan sistem akuntansi yang digunakan oleh koperasi jasa keuangan syariah dengan berbagai komponen yang turut serta didalamnya seperti organisasi, prosedur, otoritas, sistem akuntansi, sistem pengendalian internal, manusia.

Organisasi merupakan bentuk dari lembaga dalam hal ini adalah koperasi syariah sehingga dalam menajalankan operasional usahanya harus berdasarkan prinsip keuangan secara syariah. Prosedur merupakan keseluruhan tata cara yang dijadikan sebagai standar dalam operasional usaha seperti SOP. SOP ini harus dijalankan dengan baik dan penuh dengan kedisiplinan agar setiap kegiatan berjalan sesuai dengan prosedur sehingga mudah untuk mengetahui kesalahan. Otoritas merupakan wewenang dalam menjalankan SOP yang dipegang oleh jabatan secara fungsional dalam lembaga koperasi syariah. otoritas ini juga sudah dicantuman dalam SOP sehingga setiap jabatan fungsional masing-masing staf sudah meiliki batas kewenangan yang telah ditentukan.

Sistem akuntansi merupakan komponen dalam sistem untuk menjalankan setiap pencatatan sampai pada pelaporan keuangan sesuai dengan prinsip-prinsip akuntansi dengan mengedepankan obyektifitas serta relevansi setiap pencatatan. Sistem pengendalian intern merupakan bentuk pengawasan yang dilakukan oleh Top Manajemen dalam hal ini adalah Manajer sebagai penanggungjawab operasional usaha. 
Manusia merupakan bagian dari sistem yang menjalankan secara keseluruhan dari berbagai komponen yang sudah menjadi bagian system. Manusia merupakan unsur yang terpenting dalam sistem karena system yang telah dibuat dengan berbagai desain pada akhirnya yang menajalankan adalah manusia apabila semua orang yang ada dalam KJKS tidak menjalankan sesuai dengan aturan dan tanpa kedisiplinan maka system tidak berjalan dengan semestinya.

Hasil penelitian ini didapatkan bahwa desain akuntansi anti korupsi yang diperoleh adalah penggunaan sistem akuntansi yang sudah ditentukan dengan menekankan pada pencatatan yang benar melalui validasi bukti tranaksi sesuai dengan otoritas dibawah pengendalian Top Manajemen dengan cara memastikan setiap pencatatan adalah sama dengan bukti transaksi yang ada dalam hal ini dilakukan dengan obyektivitas yang tinggi tanpa ada niat atau keinginan untuk merubah data. Selain itu perlu memperhatikan faktor manusianya karena dalam teori GONE dan Segitiga Kecurangan menunjukkan bahwa tindakan korupsi lebih banyak didasari oleh rasionalisasi dan peluang. Oleh karena itu sistem yang dibuat dalam menjalankan operasional usaha harus memberikan rasa nyaman kepada setiap manusia yang terlibat dalam komponen sistem tersebut. Terlebih lagi karena manusia memiliki sifat yang berbeda maka perlu penekanannya pada faktor manusia sehingga sistem akuntansi dengan pengendalian internal harus dilakukan dengan benar sesuai dengan sistem yang diberlakukan. Dengan memperhatikan rasa nyaman dari manusia (dalam hal ini adalah seluruh pengelola koperasi) yang termasuk komponen sistem maka akan tercipta suasana yang aman terhadap segala aset usaha yang dimiliki.

Desain akuntansi anti korupsi yang ideal dari penelitian ini pada intinya adalah melaksakan sistem akuntansi yang obyektif sesuai dengan prosedur akuntansi yaitu mulai dari pencatatan sampai pada pelaporan keuangan dengan memperhatikan pengendalian internal yang tidak memberikan tekanan kepada staf sehingga memberikan rasa nyaman pada saat melaksanakan tugas. Perhatian dan penghargaan terhadap hasil kinerja staf dan memberikan motivasi merupakan tindakan preventif untuk menghindari terjadinya kecurangan sehingga didapatkan desain akuntansi anti korupsi yang ideal.

\section{Temuan dalam Penelitian}

Proses mendesain akuntansi anti korupsi tidaklah mudah karena sudah banyak terjadi tindakan korupsi dengan berbagai latar belakang yang berbeda. Selama penelitian 
ini dilakukan berdasarkan data dan hasil analisa serta pembahasan dengan beberapa teori telah ditemukan :

1. Pencatatan akuntansi pada kedua KJKS telah dilaksanakan sesuai dengan sistem akuntansi yang ada dengan pengendalian internal yang telah dilakukan dengan baik mulai dari proses pencatatan, bukti transaksi dan pelaporan keuangan baik harian, bulanan maupun tahunan meskipun masih ada peluang dalam hal bukti transaksi yang ada pada KJKS manfaat dan KJKS Harapan Surabaya yaitu tidak adanya nomor bukti transaksi yang tercetak dalam bukti transaksi itu secara langsung yang tidak dapat digantikan dengan tulisan tangan. Walaupun sudah ada satu bukti transaksi yang sudah ada nomor bukti transaksi yaitu pada KJKS Harapan Surabaya di bukti transaksi tanda penarikan.

2. Sistem pengendalian internal pada kedua KJKS dilakukan oleh manajer sebagai penanggungjawab operasional koperasi. Pengendalian internal yang dilakukan selain tindakan yang bersifat detektif dalam hal pengecekan setiap catatan yang disesuaikan dengan bukti transaksi juga dilakukan dengan tindakan preventif yang bersifat pada kenyamanan staf dalam bekerja. Tindakan preventif tersebut dilakukan untuk memberikan rasa nyaman kepada staf terhadap semua pekerjaan yang dilakukan dengan penghargaan melalui pemberian insentif gaji yang cukup dan memperlakukan staf dengan baik dengan tujuan untuk mengurangi tindakan curang.

3. Kedua KJKS memiliki staf yang relatif sedikit sehingga deskripsi pekerjaan sering dirangkap atau beban kerja menjadi lebih banyak sehingga otorisasi dalam hal pekerjaan menjadi lebih rumit meskipun sudah diberikan wewenang kepada setiap staf. Hal ini menyebabkan SOP yang ditetapkan menjadi fleksibel atau dapat berubah dengan mengacu pada kebijakan dari manajer.

4. Pengendalian dipercayakan oleh manajer secara penuh menyebabkan pengendalian internal terpusat pada top manajemen. Pekerjaan manajer ini juga diawasi oleh pengurus melalui sistem pengawasan melekat dan fungsional sehingga manajer tidak dapat berperilaku diluar aturan SOP meskipun pada operasional sistemnya manajer diberikan kesempatan untuk menentukan kebijakan personalia dalam rangka menghindari tindakan curang. 


\section{SIMPULAN DAN SARAN}

\section{Simpulan}

Sistem akuntansi yang diterapkan oleh KJKS Manfaat dan KJKS Harapan surabaya mengacu pada SOP yang diberlakukan dengan membentuk sistem dari beberapa komponen yang terlibat. Sistem akuntansi yang dilakukan sudah sesuai dengan yang ada yaitu menerapkan pencatatan akuntansi mulai dari simpanan dan pembiayaan dengan bukti-bukti transaksi yang sudah divalidasi oleh maisng-masing pemegang otoritas dengan pengendalian internal yang dilakukan oleh manajer. Sistem akuntansi yang diterapkan adalah pencatatn bukti transaksi ke dalam jurnal untuk catatan harian selanjutnya pada buku besar pembantu yang digunakan untuk mencatat simpanan maupun pembiayaan anggota yang pada akhirnya disajikan dalam bentuk laporan keuangan.

Sistem akuntansi yang diterapkan tidak lepas dari pengendalian internal yang digunakan untuk menjaga otoritas atau wewenang dalam rangka menjaga kemananan aset koperasi. Pengendalian internal yang dilakukan mengacu pada SOP dengan mengutamakan ketaatan terhadap semua prosedur yang telah ditetapkan meskipun terdapat kebijakan oleh manajer melalui persetujuan dari pengurus yang dipertanggungjawabkan kepada anggota yaitu mengenai kewenangan dalam pekerjaan mengingat jumlah staf yang dimiliki tidak banyak sehingga pekerjaan menjadi lebih banyak atau tidak terdistribusi sesuai dengan fungsional masing-masing.

Sistem akuntansi dan pengedalian internal yang diterapkan sudah sesuai dengan aturan meskipun dengan kebijakan tersendiri. Tindakan preventif yang dilakukan adalah memberikan rasa nyaman terhadap staf agar tidak melakukan tindakan korupsi baik secara mandiri maupun secara bersama. Tindakan detektif dalam sistem akuntansi pengendalian internal dilakukan dengan selalu melakukan pengecekan terhadap semua bukti transaksi dan catatan yang ada. Tindakan represif tidak pernah terjadi karena belum pernah ditemukan adanya tindakan korupsi yang dilakukan oleh staf maupun manajer. Bentuk desain akuntansi anti korupsi yang dapat disimpulkan dari penelitian ini adalah penerapan sistem akuntansi berdasar pada SOP dengan cara pengorganisasian bukti transaksi melalui otorisasi validasi keabsahan sehingga bukti tersebut dapat digunakan sebagai pencatatan yang obyektif dengan pengawasan internal dari top manajemen berdasar pada kepatuhan dalam menyelesaikan pekerjaan kemudian memberikan 
penghargaan atas pekerjaan yang telah diselesaikan serta memberikan motivasi yang baik sehingga tidak terjadi kecurangan.

\section{Saran}

Penerapan sistem akuntansi sudah dijalankan sesuai dengan mekanisme yang ada dengan alur sesuai dengan sistem meskipun dengan jumlah staf yang relatif sedikit. Penghargaan terhadap kinerja staf juga sudah dilakukan dengan menunjukkan atau membuata suasana nyaman dalam bekerja tanpa intervensi yang dibuat untuk mencari kesalahan staf dengan kata lain tindakan detektif telah dilakukan dalam rangka membantu staf untuk lebih memahami pekerjaan sesuai dengan sistem yang dibuat. Saran yang dapat diberikan adalam berikan motivasi pada staf atau karyawan untuk melaksanakan tugas dengan baik tanpa harus membebani pekerjaan yang besar.

Deskripsikan beban kerja sesuai dengan SOP yang ada sehingga perlu ditambahkan jumlah staf dengan tetap memperhatikan penghargaan terhadap staf dengan memberikan rasa nyaman dalam bekerja dan memberikan gaji yang cukup untuk hidup layak sehingga staf akan merasa nyaman dan akan melaksanakan pekerjaan dengan baik, dengan demikian secara otomatis sistem akuntansi akan berjalan dengan sendirinya .

\section{DAFTAR PUSTAKA}

Afkar, Taudlikhul. 2012. Pengaruh Pembiayaan Yang Diberikan Terhadap Dana Pihak Ketiga Perbankan Syariah di Indonesia (Bank Umum Syariah dan Usaha Unit Syariah). Jurnal Studi Islam. Vol 2.September no 1.

Afkar, Taudlikhul. 2015. Pengantar Akuntansi. Surabaya : Staina Press.

Afkar, Taudlikhul. 2016. Efektivitas Pengendalian Preventif, Pengendalian Detektif, Dan Pengendalian Represif Terhadap Pencegahan Kecurangan Akuntansi. Majalah Ekonomi. Volume XXI, No. 2, Desember ISSN 1411-9501

Afkar, Taudlikhul., Miradji, M. Afrizal., Hariawan, Ferry. 2018a. The Influence Of Anti Corruption Values In Honesty, Awareness, And Independence On The Application Of The Principles Of Islamic Financial System. Majalah Ekonomi.Vol. XXIII No.1 Juli 2018. ISSN No. 1411-9501

Afkar, Taudlikhul., Miradji, M. Afrizal., Hariawan, Ferry. 2018b. Analisis Penerapan Prinsip Sistem Keuangan Syariah dalam nilai-Nilai Anti Korupsi : Kedisiplinan, tanggung Jawab, Kerja Keras. Prosiding Conference on Economic \& Business Adi Buana University of Surabaya. "Budaya Bisnis Berbasis Ekonomi Hijau di Era Industri 4.0". 4 Agustus 2018. ISBN 978-602-5793-24-0. Halaman 21-30

Albrecht, W. Steve and Chad O Albrecht. 2003. Fraud Examination. New York : Thompson South Western.

Angha, Nader. 2002. Teori I Kepemimpinan berdasarkan Kecerdasan Spiritual, Jakarta: Serambi

Bologne dan Lindquist. 1995. Fraud Auditing and Forensic Accounting. New York : John Willey and Sons. 
Cressey, D. 1953. Other People's Money : a Study in the Social Psychology of Embezzlement. Glencoe, IL : Free Press.

Dubnick, Melvin. 2005. Accountability and the Promise of Performance. Public Performance and Management Review (PPMR), 28 (3), March 2005

Durkheim, Emile. 1964. The Division of Labor In Society. New York : The Free Press, New Delhi, Prentice Hall of India 1969.

Fauwzi. 2011. Analisis Pengaruh Keefektifan Pengendalian Internal, Persepsi Kesesuaian Kompensasi, Moralitas Manajemen terhadap Perilaku Tidak Etis dan

Kecenderungan Kecurangan Akuntansi. Jurnal Akuntansi Universitas Diponegoro Semarang.

Gitosudarmo, Indriyo dan Najmudin, Mohammad. 2003. Anggaran Perusahaan. Yoyakarta : BPFE.

Hakim, Uminah. 2014. Eksistensi Akuntansi Forensik dalam Penyidikan dan Pembuktian Pidana Korupsi.Unnes Law Journal.ISSN 2301-6744.

Handoyo, Eko . 2009. Pendidikan Anti Korupsi. Semarang: Widyakarya Press

Krismiadji. 2005. Sistem Informasi Akuntansi. Yogyakarta : UPP AMP YKPN.

Kemdikbud RI. 2011. Pendidikan Anti Korupsi Untuk Perguruan Tinggi. Jakarta : Kemdikbud

Ludigdo, U. 2006. Strukturisasi Praktik Etika di Kantor Akuntan Publik: Sebuah Studi Interpretif. Proceeding Simposium Nasional Akuntansi IX Padang: 1-22.

Mulki, Khaikal. 2011. Analisis Pengaruh Moral Hazard terhadap Pembiayaan Bank Syariah di Indonesia. Jakarta : UIN Syarif Hidayatullah.

Mulyadi. 2001. Sistem Akuntansi. Jakarta : Salemba Empat.

Pierre, Jon. 2007. Handbook of Public Administration. London : SAGE Publication Ltd. Prasojo, Eko, Teguh Kurniawan, Defny Holidin. 2007. Refomasi dan Inovasi Birokrasi: Studi di Kabupaten Sragen. Jakarta: Departemen Ilmu Administrasi FISIP UI dan Yappika-CIDA.

Rahardjo, Satjipto. 1983. Hukum dan Perubahan Sosial: suatu Tinjauan Teoretis Serta Pengalaman-pengalaman di Indonesia. Bandung: Alumni

Rama, Dasaratha V dan Jones, Frederick L. 2008. Accounting Information System. Jakarta : Salemba Empat.

Ramamoorti, S. 2008. The Psycology and Sociology of Fraud : Integrating The Behavioral Sciences Component Into Fraud and Forensic Accounting Curricula. Issues in Accounting Education vol, 23

Romney, M.,Albrecht, W.S., Cherrington, D.J. 1980. Auditors and the Detection of Fraud. New York : Pearson-Prentice Hall.

Shafique, dkk. 2012. Liquidity and risk Analysis of Islamic Banking System During Global Financial Crises, Liquidity Analysis of Islamic Financial system During Financial Crunch 2008. Kuwait Chapter of Arabian Journal of Business and Management Review.Vol 1, No. 8

Shleifer, Andrei and Robert. W. Vishny. 1993. Corruption, Quarterly of Journal Economy. Vol.CVIII, August 1993. MIT Press, Cambridge,Massachusetts, pp 598-617

Silalahi, T.B. 1997. Tak Perlu Dibentuk Badan Antikorupsi, Kompas Online. http:.//www-kompas.com/9706/23/POLITIK/tak-html

Sjaifudin, Hetifah. 2002. Inovasi, Partisipasi, dan Good Governance. Jakarta

Snape, Fiona Robertson. 1999. Corruption Colussion and Nepottism in Indonesia. Third Word Quarterly Vol 20 No 3 The Politic Coruption. 
Sugiyono. 2009. Metode Penelitian Bisnin Pendekatan Kualitati, Kuantitatif, R \& D. Bandung: CV. Alfabeta.

Sugono, Dendy. 2008. Kamus Besar Bahasa Indonesia, Jakarta: Pusat Bahasa Departemen Pendidikan Nasional

Supardi, Endang. 2004. Kiat Mengembangkan Sikap Mandiri. Bandung : Departemen Pendidikan Nasional

Suradi. 2013. Mengapa Seseorang Korupsi?. Widyaiswara Madya Balai Diklat Keuangan Palembang

Tampubolon, Robert. 2005. Risk and Systems-based Internal Auditing. Jakarta : Elex Media Komputindo.

US Government. 1979. Foreign Corrupt Practices Act of 1977. US Code Sepplement II, Title 15, Slesction 78. Washington DC : Printing Office.

Wilopo. 2006. Analisis Faktor-faktor yang Berpengaruh Terhadap Kecenderungan Kecurangan Akuntansi : Studi pada Perusahaan Publik dan Badan usaha Milik Negara (BUMN) di Indonesia. Jurnal Riset Akuntansi Indonesia Vol, 9.

Wiratmaja, I Dewa Nyoman. 2010. Akuntansi Forensik Dalam Upaya Pemberantasan Tindak Pidana Korupsi. Bali : Fakultas Ekonomi- Udayana. 